\title{
“LIVING DECENT LIVES” SOCIAL OTHER AND THE SELF IN KAZUO ISHIGURO'S NEVER LET ME GO
}

\section{RISHAV PAUL}

Student at Jadavpur University, Kolkata, India

Pursuing M.A. (English)

\begin{abstract}
The twenty-first century has seen a prolific proliferation of dystopian novels, most of which focus on humanity's enduring struggle to find cures for Mankind's greatest fear: disease, or, to be more precise, fatal disease. Novel franchises like "The Maze Runner" specifically focus upon finding a cure for virus pandemics and plagues, while zombie apocalypses are usually heralded by a single-point outbreak mechanism. However, in such a literary genre, Kazuo Ishiguro's Never Let Me Go stands out, not because of the wide critical acclaim that it has received, but also because of the manner in which it addresses disease and death, not as enemy to be defeated, but rather an inevitability to be accepted. The protagonists of the story: Kathy, Tommy and Ruth are all donors, manufactured human beings who are harvested for organs which are needed by their human originals, but who, despite knowing their fates as repositories of spare parts, dare to dream and to enact actual human lives, starting at their school, Hailsham

My paper shall attempt to outline the protagonists as both the Other in a society which refused to accept them as normal in their identities as donors, at the same time highlighting the separate identity they form within the community of donors, while trying to illustrate their position in a narrative about healthcare practices. I shall explore the roles Kathy and Tommy play in each others' lives as they attempt to find themselves and break boundaries, independent of a society which has assigned them finite roles.
\end{abstract}

KEYWORDS: Living Decent Lives Social Other and the Self in Kazuo Ishiguro's Never Let Me Go

Received: Jun 10, 2015; Accepted: Jun 29, 2015; Published: Jul 03, 2015; Paper Id.: IJELAUG20172

\section{INTRODUCTION}

I apologize that I start off my paper by rather perverting the lyrics of one of John Lennon's iconic songs. Imagine, ladies and gentlemen, a world where disease or injury has been conquered. Imagine a world where readymade replacements for the failing organs of human beings are found as easily as meat at the butcher's. That is the story of Kazuo Ishiguro's dystopian novel Never Let Me Go. It is a story about an England so shattered by war, so scared of death, that they create an entire new generation of 'students', or clones, if you will, to try to defeat Death, or at least delay it as much as possible. Now, 'Isn't that a Utopia?' one might ask. Indeed, it might be. For the humans who seek to extend their lifespan. But what about the clones, the organ donors, whose sole purpose of existence seem to be to support the existence of others? That is the central question at the heart of Never Let Me Go: a question regarding the essential humanity of the clones. It is a question asked frequently throughout the novel to the reader, and towards the end, it is also a question asked by the protagonist Kathy. "Did someone think we didn't have souls?"

Now, let me define the other. Otherness, the characteristics of the other, is the state of being different from and alien to the social identity of a person and to the identity of the Self. Another way of describing "The other" is to 
portray oneself at the centre of focus and "The Other" on the outside. The other portrays everything the Self is not, and in traditional phenomenology, the Other is by definition a contributing factor to understanding the Self, by opposition. Hegel introduced the concept of the other as a constituent part of self-consciousness which complements the propositions about self-awareness. (Hegel)

The plot of Never Let Me Go is quite simple, but the questions it asks are quite profound. Ishiguro tells us the story of three 'students', as it were, named Kathy, Ruth and Tommy. They all attended an elite school named Hailsham, the purpose of which is explained later to us: it was simply a school to rear the clones, the organ donors, from childhood itself, and allow them to live decent lives before they went through their cycles of organ donation, which ultimately resulted in their death. Juxtaposed between the seemingly idyllic Hailsham School and the fate which has inevitably awaited her and her closest friends, Kathy, the narrator of the story, struggles to come to terms with herself and with the truth that they, the students, are in many ways, the social Other; unwitting, almost inanimate, inferior to the actual human beings whose medical needs are fulfilled by them.

Miss Emily, the guardian who runs Hailsham, wants to provide a sheltered childhood to the donors, protecting them from the harsh reality of their future, but the inevitability of their futures hangs like a pall over the protagonists' last years at Hailsham. The art that they create as children is carried away by the mysterious Madame, to a fabled gallery, which Kathy later learns truly existed, if only to prove to people that these clones actually had souls, were actual humans, instead of inferior machines. Kathy also narrates an incident where the enigmatic Madame had tears in her eyes when she saw Kathy dancing to the song 'Never Let Me Go' by Judy Bridgewater. The story of the near normalcy of the lives that Kathy, Ruth and Tommy lead at Hailsham, consisting of all the teen tantrums, forming and breaking apart of friendships, is often violated by Ishiguro's constant reminders that they aren't normal; they aren't their human selves, rather, they are part of what society would call the Other. There is a very prominent line dividing the donors from 'normal' human beings. As Andrew C. Okolie puts it, "Social identities are relational; groups typically define themselves in relation to others. This is because identity has little meaning without the "Other". Power is implicated here, and because groups do not have equal powers to define both self and the other, the consequences reflect these power differentials. Often notions of superiority and inferiority are embedded in particular identities." (Okolie) This is amply illustrated by Miss Lucy's diatribe, when Kathy and her classmates are in their final years at Hailsham.

But then Miss Lucy said again, this time much more gently:

"Peter, go on. Please tell the others what you were just saying."

Peter shrugged. "We were just talking about what it would feel like if we became actors. What sort of life it would be."

"Yes," Miss Lucy said, "and you were saying to Gordon you'd have to go to America to stand the best chance."

Peter J. shrugged again and muttered quietly: "Yes, Miss Lucy."

But Miss Lucy was now moving her gaze over the lot of us. "I know you don't mean any harm. But there's just too much talk like this. I hear it all the time, it's been allowed to go on, and it's not right." I could see more drops coming off the gutter and landing on her shoulder, but she didn't seem to notice. "If no one else will talk to you," she continued, “then I will. The problem, as I see it, is that you've been told and not told. You've been told, but none of you really understand, and I dare say, some people are quite happy to leave it that way. But I'm not. If you're going to have decent 
lives, then you've got to know and know properly. None of you will go to America; none of you will be film stars. And none of you will be working in supermarkets as I heard some of you planning the other day. Your lives are set out for you. You'll become adults, and then before you're old, before you're even middle-aged, you'll start to donate your vital organs. That's what each of you was created to do. You're not like the actors you watch on your videos, you're not even like me. You were brought into this world for a purpose, and your futures, all of them, have been decided. So you're not to talk that way anymore. You'll be leaving Hailsham before long, and it's not so far off, the day you'll be preparing for your first donations. You need to remember that. If you're to have decent lives, you have to know who you are and what lies ahead of you, every one of you." (Ishiguro)

The biological differences between 'normal' humans and donors are also highlighted in the different attitudes towards sex. Donors couldn't conceive babies, and as such, the guardians would caution the students about sex, in their biology classes.

Then there was the whole business about our not being able to have babies. Miss Emily used to give a lot of the sex lectures herself, and I remember once, she brought in a life-size skeleton from the biology class to demonstrate how it was done. We watched in complete astonishment as she put the skeleton through various contortions, thrusting her pointer around without the slightest self-consciousness. She was going through all the nuts and bolts of how you did it, what went in where, the different variations, like this was still Geography. Then suddenly, with the skeleton in an obscene heap on the desktop, she turned away and began telling us how we had to be careful who we had sex with. Not just because of the diseases, but because, she said, "sex affects emotions in ways you'd never expect." We had to be extremely careful about having sex in the outside world, especially with people who weren't students, because out there sex meant all sorts of things. Out there people were even fighting and killing each other over who had sex with whom. And the reason it meant so much - so much more than, say, dancing or table-tennis-was because the people out there were different from us students: they could have babies from sex. That was why it was so important to them, this question of who did it with whom. And even though, as we knew, it was completely impossible for any of us to have babies, out there, we had to behave like them. We had to respect the rules and treat sex as something pretty special. (Ishiguro)

Thus we see how the inherent differences, the "Other-ness" of the donors is emphasized even in their sexual relationships.

The abject despair and loneliness that the donors feel, even when they are in a group, conversing with each other, is clearly reflected in Ruth's cruel observation that they aren't modelled upon good people, on fine upstanding citizens of society, but rather on 'trash', on "junkies, prostitutes, winos and tramps." It is similar to the existentialist philosophy expressed by $20^{\text {th }}$ century scholars like Sartre, Camus and Beckett, in their works. One can easily imagine Kathy, Ruth and Tommy in the position of a Mersault, or a Hamm and Clov, predestined to live out their assigned lives. Ruth says this when the three of them, along with some seniors named Chrissie and Rodney decide to follow a woman who might be Ruth's 'possible', that is, the woman on whom Ruth is modelled, but are utterly disappointed when they find themselves completely mistaken. Ruth expresses the feeling of isolation and "Other-ness" lurking in each of their minds when she says that the woman managing the art gallery that the group visits, would probably have been horrified and would never have mistaken them for art students, if she had known what they actually were: that is, donors. Through this, Ishiguro also highlights society's intense apathy, and indeed, prejudice against donors. It is not unlike the prejudice blacks have faced in white supremacist America, and the apathy which most natives faced and indeed still face at the hands of the colonial 
powers. Other research into, for instance, the Benjamin Franklin effect, shows that we have a startling tendency to come to hate people who we treat badly. If we're experiencing guilt about our treatment of some person, or group, or class, and having trouble reconciling that guilt with our notion of ourselves as good people, our brains are extremely adept at resolving the situation by "Othering" the people we feel that we've wronged. If we dehumanise someone, and distance our empathy with them, then we won't have to feel bad about the shabby way we've treated them.

The general repugnancy and revulsion that the 'normal' population of England felt towards the donors is illustrated in clear cut terms in the conversation that Kathy and Tommy have with Miss Emily and Marie-Claude, who turns out to be the statuesque Madame who used to visit Hailsham all those years ago.

However uncomfortable people were about your existence, their overwhelming concern was that their own children, their spouses, their parents, their friends, did not die from cancer, motor neurone disease, heart disease. So for a long time you were kept in the shadows and people did their best not to think about you. And if they did, they tried to convince themselves you weren't really like us. That you were less than human, so it didn't matter. It's one thing to create students, such as yourselves, for the donation programme. But a generation of created children who'd take their place in society? Children demonstrably superior to the rest of us? Oh no. That frightened people. They recoiled from that." (Ishiguro)

Kathy and Tommy go to great lengths to gain an audience with 'Madame', dreaming that she can delay their cycle of donations if they can prove that they are in love with each other, thus proving that they indeed have souls, and are not soulless machines meant only to sacrifice their lives and organs for people. But, in the manner of Langston Hughes' dream about Harlem, (Hughes) this is a 'dream deferred.' The donors have to go through their cycle of donations and then die, irrespective of how much in love they might be. They have none of the free will that Voltaire talks about in Candide. (Voltaire) The illusion of being able to live longer, just by proving that they are as much human as a 'normal person', is in the end, shattered. Despite the fact that Miss Emily quashes the high hopes they have in the gentlest manner possible, the undeniable truth remains that however much in love they might be, however good artists they might be, the donors have an inevitable future. The donors, especially sensitive souls like Kathy, Tommy and Ruth, in Never Let Me Go, seem to lead a miserable existence similar to the lives of the lower castes in medieval India, where shudras weren't allowed to drink water from the public well, were forced to wear chains and only wear clothes that they scavenged from dead bodies, despite the fact that they performed a function as intrinsic to society as the one the donors do here: they burned dead bodies. The inherent differences between the thought process of the donors, and normal people, is revealed to us readers in the conversation between Madame and Kathy where they talk about why Madame had cried all those years ago when she had witnessed Kathy dancing to the notes of 'Never Let Me Go' by Judy Bridgewater; Kathy believes she had cried on seeing Kathy dreaming of an impossible future, but Madame had cried because she knew that they, the donors as well as the guardians at Hailsham, were trying to hold on to an impossible past.

"There was a time you saw me once, one afternoon, in the dormitories. There was no one else around, and I was playing this tape, this music. I was sort of dancing with my eyes closed and you saw me."

"That's very good. A mind-reader. You should be on the stage. I only recognised you just now. But yes, I remember that occasion. I still think about it from time to time."

"That's funny. So do I." 
"I see."

We could have ended the conversation there. We could have said goodbye and left. But she stepped closer to us, looking into my face all the time.

"You were much younger then," she said. "But yes, it's you."

"You don't have to answer this if you don't want to," I said. "But it's always puzzled me. May I ask you?"

"You read my mind. But I cannot read yours."

"Well, you were... upset that day. You were watching me, and when I realised, and I opened my eyes, you were watching me and I think you were crying. In fact, I know you were. You were watching me and crying. Why was that?"

Madame's expression didn't change and she kept staring into my face. "I was weeping," she said eventually, very quietly, as though afraid the neighbours were listening, "because when I came in, I heard your music. I thought some foolish student had left the music on. But when I came into your dormitory, I saw you, by yourself, a little girl, dancing. As you say, eyes closed, far away, a look of yearning. You were dancing so very sympathetically. And the music, the song. There was something in the words. It was full of sadness."

“The song," I said, "it was called "Never Let Me Go."” Then I sang a couple of lines quietly under my breath for her. "Never let me go. Oh, baby, baby. Never let me go..."

She nodded as though in agreement. "Yes, it was that song. I've heard it once or twice since then. On the radio, on the television. And it's taken me back to that little girl, dancing by herself."

"You say you're not a mind-reader," I said. "But maybe you were that day. Maybe that's why you started to cry when you saw me. Because whatever the song was really about, in my head, when I was dancing, I had my own version. You see, I imagined it was about this woman who'd been told she couldn't have babies. But then she'd had one, and she was so pleased, and she was holding it ever so tightly to her breast, really afraid something might separate them, and she's going baby, baby, never let me go. That's not what the song's about at all, but that's what I had in my head that time. Maybe you read my mind, and that's why you found it so sad. I didn't think it was so sad at the time, but now, when I think back, it does feel a bit sad."

I'd spoken to Madame, but I could sense Tommy shifting next to me, and was aware of the texture of his clothes, of everything about him. Then Madame said:

“That's most interesting. But I was no more a mind-reader then than today. I was weeping for an altogether different reason. When I watched you dancing that day, I saw something else. I saw a new world coming rapidly. More scientific, efficient, yes. More cures for the old sicknesses. Very good. But a harsh, cruel world. And I saw a little girl, her eyes tightly closed, holding to her breast the old kind world, one that she knew in her heart could not remain, and she was holding it and pleading, never to let her go. That is what I saw. It wasn't really you, what you were doing, I know that. But I saw you and it broke my heart. And I've never forgotten.” (Ishiguro)

In the end, it is perhaps fitting that Kathy takes care of Ruth when Ruth goes through her cycle of donations. No 'normal' person would have been able to do the job half as well, and would not have identified with Ruth's pain. Thus 
Ruth dies with her best friend, her childhood buddy from Hailsham, by her side. They exist in a world of their own, removed from the selfish human world which only demands from them but gives them nothing in return.

\section{CONCLUSIONS}

I would like to point out that Ishiguro's book portrays Master-Slave dialectic similar to the one outlined in Hegel's Phenomenology of Spirit. (Hegel) The 'normal' human race tries to gain self-consciousness, or a sense of being a superior race, by subjugating this race of donors, by ensuring that they are subservient, existing only to serve their needs. But in doing so, do they not lose their essential humanity? By the end of the novel, we are left asking this question to ourselves: what if this situation had occurred in the real world? As power today recognizably resides in the hands of the privileged majority, would it similarly reside in the hands of 'normal' humans in a dystopian world? How then, do we distinguish ourselves from the animals from which we claim to have evolved?

\section{REFERENCES}

1. Hegel, Georg Wilhelm Friedrich. Phenomenology of Spirit. Ed. Miller Arnold and Findlay John. Oxford: Oxford University Press, 1977.

2. Hughes, Langston. "Harlem.” Hughes, Langston. Selected Poems of Langston Hughes. Ed. Edward Mcknight Kaufer. New York: Knopf Publishers, 2001.

3. Ishiguro, Kazuo. Never Let Me Go. London: Faber and Faber, 2005.

4. Okolie, Andrew C. "Introduction to the Special Issue - Identity: Now You Don't See It; Now You Do." 12 November 2009.TaylorandFrancisOnline.8June2017

<http://www.tandfonline.com/doi/abs/10.1207/S1532706XID0301_01?journalCode=hidn20\&>.

5. Voltaire. Candide. New York: Dover Publications, 1991. 